水文・水資源学会誌 J. Japan Soc. Hydrol. \& Water Resour. Vol. 9. No. 4 (1996) pp. $330-339$

\title{
パイプ流が斜面安定に与える影響
}

\section{The Influence of Pipe Flow on Slope Stability}

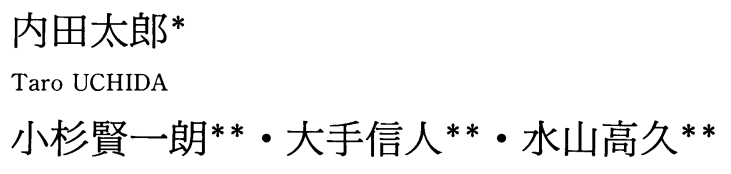

Ken'ichiro KOSUGI • Nobuhito OHTE • Takahisa MIZUYAMA

\author{
(京都大学大学院) \\ Graduate School, Kyoto University
}

(京都大学農学部)

Faculty of Agriculture, Kyoto University.

Well connected macropores running almost parallel to surface, are commonly found in forest soil. It is called "soil pipe" and water flow which go through them are called "pipe flow". This paper reviews the studies on the influence of water flow in soil pipe on slope stability with regard to rainfall intensity, and present a guideline for more practical discussion. In the case of normal rainfall event, soil pipes contribute to quick discharge of rain water which result in slope stability. Soil pipes, however, are a dead-ended pathway, which do not always work for rapid runoff system and induce slope failure. On the other hand, in the case of large rainfall event, soil pipes may not contribute to slope stability through excess infiltration beyond the drainage ability of lateral pipes and they are collapsed by underground erosion. These phenomena bring about high pore water pressure and slope failure. In order to understand and evaluate the influence of pipe flow on slope stability, three aspects should be studied: 1) are these phenomena universal? 2) quantative evaluation of influence on rain-runoff process, 3) how do they change their structure?

Key ward: Pipe flow, Slope stability, Slope failure, Runoff system

山腹斜面土層内には地表面とほほ平行にパイプと呼ばれる連続した空洞が存在することが広く確認されている。こうしたパイプ による水移動が斜面安定に与える影響について, 研究の現状を検討し, 解明すべき問題を提示する. 本稿ではパイプ流の斜面安定に 与える影響を通常の降雨時の現象と大きな降雨時の現象に分類した. 通常の降雨時にはパイプは良好な排水システムとして働き, 斜 面安定に寄与すると考えられる. しかし, パイプは下流端が閉塞していることも考えられ，このようなパイプは排水システムとして は不完全であるため, 崩壊の要因となることが考えられている. 一方, 大きな降雨時においては, 浸透水量の排水システムの許容量 の超過および地下侵食による排水システムの破壊が水の集中を引き起こし, パイプが崩壊の要因となることが考えられている. パイ プが斜面安定に与える影響を解明するために検討すべき事項として，1）観察される現象が空間的・時間的に普遍的か否かを検討す る，2）パイプの降雨流出過程に及ぽす影響を定量的に評価する，3 ）パイプの構造の動的変化を評価する，の 3 点が考えられる.

キーワード：パイプ流，斜面安定，崩壊，排水システム

\section{I .はじめに}

山腹斜面土層内には鉛直及び地表面とほほ平行に パイプと呼ばれる連続した空洞が存在することが広 く確認されている.このパイプは小動物の活動, 植 物根の腐朽，地下水による侵食など様々な要因によ
り形成されると考えられている(Beven and Germann, 1982など).これらパイプが関与する水移動は 山腹斜面内の降雨流出過程はもとより, 崩壊・地形 発達に関与しうる要因であると考えられている(北 原, 1995など). 本稿では, このうち斜面に平行に発達 するパイプに注目し，こうしたパイプによる水移動

*京都大学大学院 $\overline{\mathbf{T}} 606$ 京都府京都市左京区北白川追分町

Graduate School, Kyoto University, Oiwake-cho, Sakyo-ku, Kyoto 606

**京都大学農学部

Faculty of Agriculture, Kyoto University 
が斜面安定に与える影響について, 研究の現状を検 討する.

ここではパイプ流の斜面安定に与える影響を図 - 1 に示すとおり通常の降雨時の現象と大きな降雨 時の現象に分類し，それぞれについて検討する。 な お, ‘大きな降雨’の範囲はパイプ網それぞれによって 異なることが予想される。

図一 1 に示すとおり, 通常の降雨時にはパイプは 良好な排水システムとして働く。このことから，パ イプは斜面安定に寄与すると考えられる。しかし， 小動物の活動や植物根等により形成されたパイプに は下流端が閉塞していることが考えられる。このよ うな，下流端の閉塞したパイプは排水システムとし ては不完全であるため, 局所的な水の集中を引き起 こし, 崩壊要因となることが考えられる. 一方, 大 きな降雨時においては，図一1に示すとおり，パイ プは排水システムの許容量超過による水の集中及び 地下侵食による土質強度低下, 排水システム破壊に よる水の集中などの現象により崩壊の要因となるこ とが考えられる.

そこでまず，本稿ではパイプの斜面の排水システ ムとしての働きをパイプ流量の観測等の結果から明 らかにし，パイプの排水効果を定量化するにあたっ ての課題を検討する. 次に，図一 1 に示す $1 \sim 14$ の 流れを通常の降雨・大きな降雨に分類し，パイプの 斜面安定及び崩壊への関与について検討する. 最後 に, パイプが斜面安定に与える影響を解明する上で の今後の課題について整理する.

\section{II . 降雨流出過程におけるパイプ}

地下に連続した大きな孔隙が存在するのであるか ら，パイプは地下の水の移動に大きな影響を与える ことは容易に想像ができる。このため, 林地など地 表流があまり見られない地域において，降雨に対し て応答の早い地下水流出が生じることを説明する機 構として, Jones(1971)以来, 斜面土層内におけるパ イプの存在は注目されてきた。 そこで本章では, 図 - 1 に示すパイプが良好な排水システムとして働く ことに着目した研究をレビューし, その効果の定量 化に向けての課題を検討する.

\section{1 ．パイプ流の流速・流量観測}

パイプの降雨流出過程における影響を検討するた めに，まずトレーサーによる側方流及びパイプ流の 流速観測が行われた (Mosely，1982；田中ら，1984な

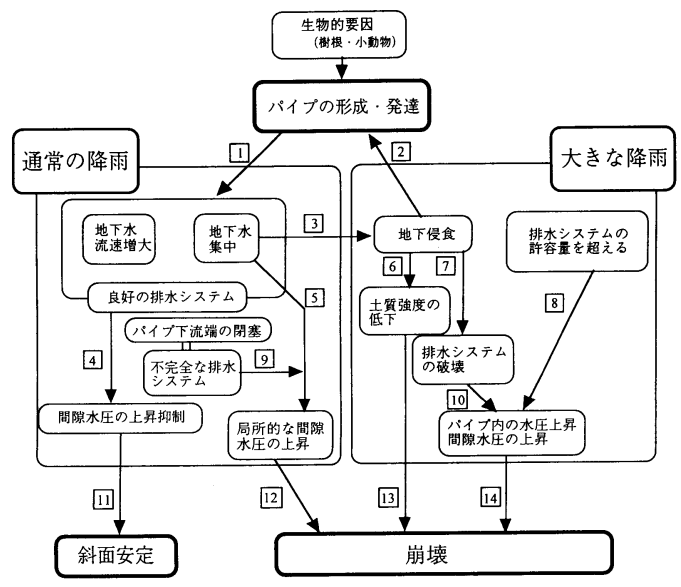

図一 1 パイプ形成と斜面崩壊の関係のダイアグラム

ど).これらの結果より, 斜面内には地表流に匹敵す る速い流れが存在することが明らかにされた。

これらの研究に次いで, 斜面に掘られたトレンチ においてパイプ流量の観測が行われてきた。 パイプ の流出に占める役割を定量的に規定するために，卜 レンチにおける総流出量とパイプ流量の観測を, Tsukamoto and Ohta（1988）は 0 次谷出口で, 北 原・中井(1992) は 1 次谷側壁斜面でそれぞれおこ なった。これらによるといずれの場合においても降 雨時においては $50 \%$ 以上がパイプ流出により賄われ ることが示された。

また，Nieber and Waner(1991)は均質な土層を もった斜面に円筒形のパイプが存在する場を想定し た浸透流出シミュレーションを行い，パイプからの 流出量, マトリックスからの流出量をパイプの直径, 長さ，密度等を変化させ，計算した。その結果から もパイプ流が斜面からの総流出量の大部分を占める ことが示された。

以上の研究より，図一 1 に示すとおりパイプ流は, 特に降雨時において, 流速が地表流に匹敵し, 流量 が斜面からの総流出量のかなりの部分を占めること が明らかになった。このことから，少なくとも通常 の降雨の場合はパイプは良好な排水システムと考え ることができる.

\section{2. パイプ流出のモデル化に向けての課題}

パイプの降雨流出過程に及活す影響をより定量的 に表現するために，パイプを含めた流出モデルの構 築が望まれる，そのために，今後課題となる点は次 の 3 点と考える. 
表一 1 日本におけるパイプの観察例

\begin{tabular}{|c|c|c|c|c|}
\hline 土層内の位置 & 発達地形 & 主な要因 & 研究例 & 地質 \\
\hline 表層土 & & 生物的要因 & $\begin{array}{l}\text { 森林総研北海道支所内林（北原, 1989） } \\
\text { 波丘地（Tsukamoto and Ohta, 1988） } \\
\text { 常陸太田（Tsuboyama et al，1994） } \\
\text { 西三河矢作川流域（太田ら，1981） }\end{array}$ & $\begin{array}{l}\text { 火山灰層 } \\
\text { 砂質泥岩 } \\
\text { 火山灰層 } \\
\text { 花岡岩（崩填跡地） }\end{array}$ \\
\hline 下尿土 & 0 次谷出口 & $\begin{array}{l}\text { 地下水集中に } \\
\text { よる地下侵食 }\end{array}$ & $\begin{array}{l}\text { 京大芦生演習林（内田ら, 1995） } \\
\text { 東大愛知演習林（寺嶋ら, 1993） } \\
\text { 波丘地（安原ら, 1984） } \\
\quad \text { (新藤ら, 1988） } \\
\quad \text { (Tsukamoto and Ohta, 1988） }\end{array}$ & $\begin{array}{l}\text { 中古生層（石磁性） } \\
\text { 花崗岩 } \\
\text { 火山灰と泥岩風化物の混合物 } \\
\text { 火山灰と泥岩風化物の混合物 } \\
\text { 砂質泥岩 }\end{array}$ \\
\hline & $\begin{array}{l}1 \text { 次谷側壁 } \\
\text { 平衡斜面 }\end{array}$ & $\begin{array}{l}\text { 地下水集中に } \\
\text { よる地下侵食 }\end{array}$ & $\begin{array}{l}\text { 常陸太田（Tsuboyama et al, 1993） } \\
\text { 定山渓（北原,1992） } \\
\text { 愛知小原村（恩田ら,1987） } \\
\text { 鳥大蒜山演習林（小山ら, 1994） }\end{array}$ & $\begin{array}{l}\text { 火山灰層 } \\
\text { 火成岩を母材とする崩積土 } \\
\text { 花崗岩 } \\
\text { 安山岩質の凝灰角磷岩 }\end{array}$ \\
\hline
\end{tabular}

(1) パイプの構造，斜面土層内の位置の定量化・ 一般化

(2) パイプ内の運動則の解明

(3) パイプ流発生機構の解明

それぞれについて検討することにする。

1 ）パイプの構造の定量化・一般化

パイプは地形，地質，植生，生物の活動，降雨な ど様々の要因により形成, 発達, 維持され, 破壊さ れる.このためパイプの構造, 斜面土層内の位置の 定量化・一般化は困難が予想される。

さらに，実際に目に見えるパイプはパイプ網全体 のごく一部分である．また，表層土中にはパイプは 形成されても側方流の発生頻度が小さいため見た目 の構造は不明瞭であるが，依然として透水性の高い 「潜在パイプ」(塚本ら，1988）と呼ばれるものも存在 するため，その観察はますます困難となる．そこで 完全な定量化・一般化は今後の課題として，現在ま でに観察された例についてまとめ, 構造を検討する.

まず，構造を検討する上で有用と思われるパイプ の分類を行う. 表一 1 に示すとおり，パイプは土層 内の形成位置から，表層土に存在するパイプと下層 土の難透水層直上に存在するパイプとの 2 タイプに 分類することができる．斜面土層は表層土と呼ばれ る森林土層 $(\mathrm{A}$ 層及び $\mathrm{B}$ 層) と下層土と呼ばれるその 下部の基岩風化層に大別できる(塚本，1992）.形成発 達の主要因としては, 表層土のパイプは生物的要因 が，下層土のパイプは飽和側方流による地下侵食が それぞれ挙げられる. 更に, 下層土に発達するパイ
プは，地下水流動の影響を受けるため，発達場所の 地形から一次谷側壁平衡斜面と 0 次谷出口集水型斜 面に分けられる。

植物根が成因と考えられる表層土のパイプの構造 については, 北原 (1988)が平均勾配12.9度の平衡斜 面におけるパイプを石膏で固め観察した。その結果， 表層土のパイプはほとんど屈曲が見られず，断面は 離心率 $0.39 \sim 0.84$ の棈円形であることが明らかにさ れた。

下層土のパイプのうち，一次谷側壁平衡斜面のパ イプは難透水層の上縁部に沿ってその出口が観察で きる.これらのパイプの流出ハイドログラフは各パ イプ間において増水開始及びピークの時間に差がな い.このことから，合流分岐を繰り返している一つ のパイプ網が平面的に難透水層直上に広がっている と考えられるとされている(北原・中井，1992).

次に 0 次谷出口集水型斜面におけるパイプについ て検討する．中古生層の石礫性の地質に発達するパ イプを掘り返して観察したところ，出口付近では円 筒形の形状(写真一 1)を示すが上流に行くに従い平 面的な広がりを持つマトリックスが洗脱された礫層 (写真一2 ) に変化した (内田ら, $1995 \mathrm{a})$.また, 新藤ら (1988)はパイプ出口部を石膏で固め観察した結果, 図一 2 に示すとおり流出口部, 管状部, 懐部に分類 できるとしたささらにこのタイプのパイプは，谷の 合流点や難透水層の谷といった水の集中するところ に存在することが報告されている(安原ら，1984；内 田ら, 1995 a)。 


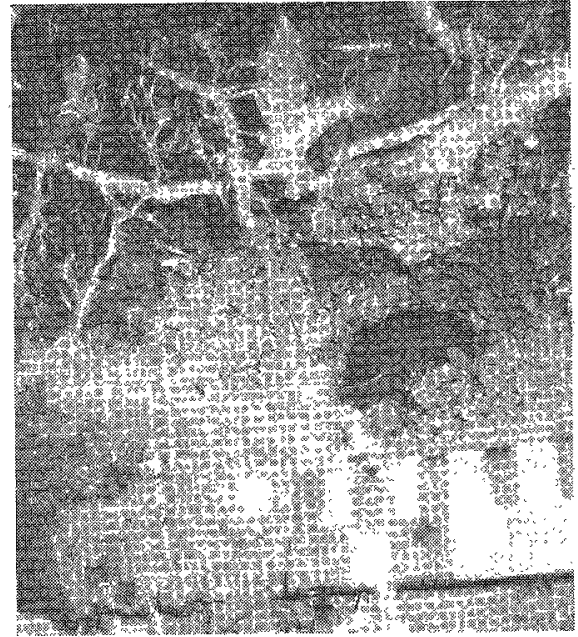

写真一 1 パイプの出口の様子

(内田ら 1995a炕よる)

\section{2) パイプ内の運動則の解明}

先に述べたようにノイプ流速は地表流に匹敵する ことが明らかさされたが，モデル化に向けてパイプ内 の水の運動則の解明が必要とな当。

パイプ内の連動則についてはバイプ内が満水状態 で水が移動する場合については，北原(1989)がパイ プを含んだサンプルを用いた透水試験を行い，パイ

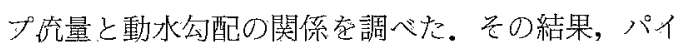
プ流注，通常のマトリックス流で考完られている， 流速が動水勾配に比例するダルジ則に従う流れで はなく、济速が動水勾配の1/2 乗に比例する流礼で あることが示さ机た。この流れはマニングの式で表 現でき，マニングの粗度係数洼パイプのタイプによ り異なることを示した。非流出時に注確認できない 「潜在パイプ」では 4 前後, 表層土飞発達寸る植物 根の跡を思わ机るパイプで0.4前後であるをした。

今後パイプ内の水流の状態を明らかれし, 非満水 時等についての検討が必要と考える。

\section{3 ) パイプ流発生機構の解明}

瑒所によってはパイプからの流出は常に生じてい るわけではない，てこでプイプ流の発生機構につい て解明卞る必要がある。まずパイプ流の発生機構を 考える上で手がかりとなる点を整理する。

a．パイプからの流出古好水の成分が大部分を 占める。

先に述べたMoselyが流速を観測したのを同じ流 域で重水素等をトレーサーに用いた流出成分分離党 行ったところ古い水が直接流出の大部分を占めてい

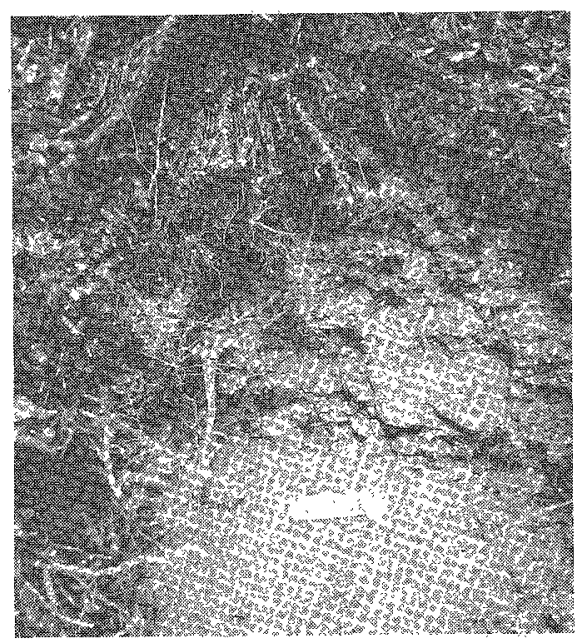

写真一2 マトリックスの洗脱された碟層の様子 (内田ら，1995aによる)

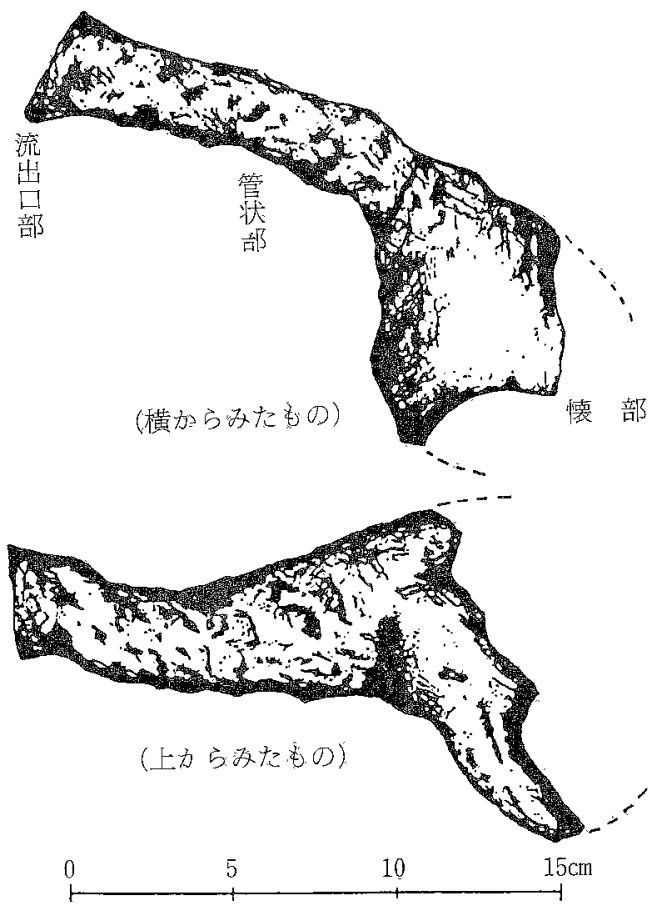

図一2 谷出口に形成されたパイプの形状 (新藤ら，1988沉よる)

t(Peárce et al., 1986; Sklash et al., 1986).

b，パイプ为らの流出の有無及び量は降雨初期の 土壤含水率及び降雨量の影響を受ける。

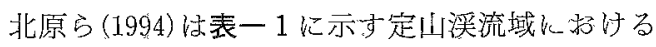
パイプ流出の観測汃ら，図一3に示寸とおり，パイ プ流出の発生の有無は降り始めからの積算降雨量の 


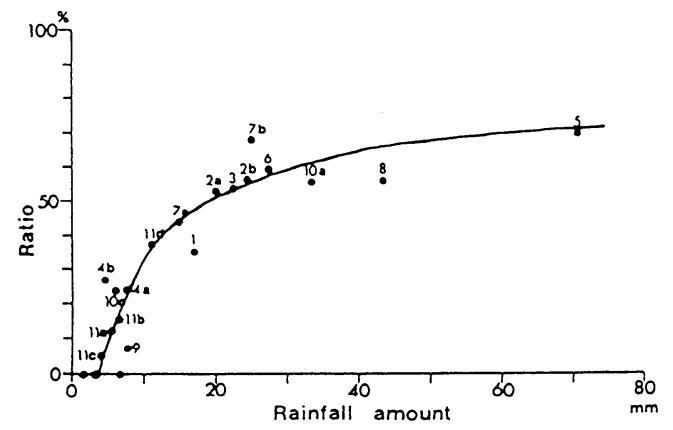

図一3 降雨量と側方浸透流にしめる全パイプ流量 の割合の関係(北原ら，1994による)

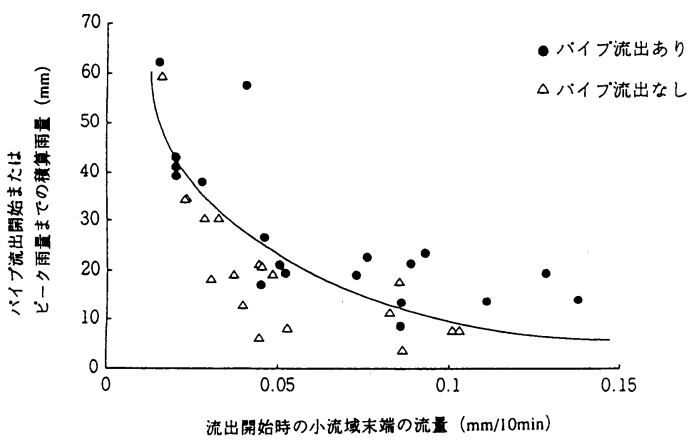

図一4 積算雨量と下流堰の初期流量によるパイプ 流出の有無(水山ら，1994による)

影響をうける．さらに流出に占めるパイプ流の割合 は降り始めからの積算降雨量と相関があり, 経験的 に次の式で表すことができるとした。

$$
\begin{array}{ll}
R_{a}=0 & \left(P_{a} \leqq P_{a c}\right) \\
R_{a}=100\left\{1-\left(P_{a c} / P_{a}\right)_{A}\right\} & \left(P_{a}>P_{a c}\right)
\end{array}
$$

$R_{a} ;$ パイプ流量の側方浸透流に占めるパーセン ト, $P_{a c}$; パイプ流の発生しない降雨量, $P_{a}$; 降雨 量, $A$; 係数

また, パイプ流の発生の有無, パイプ流量は降雨 量のみならず, 降雨初期の土䁃水分条件の影響も受 ける. 降雨初期の土壌水分条件を反映するインデッ クスとして流域の初期流量が考えられる.水山ら (1994) は，図一4に示すとおり0次谷出口のパイプ 流出の発生の有無が, 降雨初期の流量と降雨量の影 響を受けることを示した. また, 谷(1987)は, 直接流 出が主としてパイプ流出から賄われる流域における 直接流出率は, 降雨初期の流量及び総降雨量の影響 を受けることを示した.このことからパイプ流量は 降雨量及び降雨初期の土㙵水分条件の影響を受ける
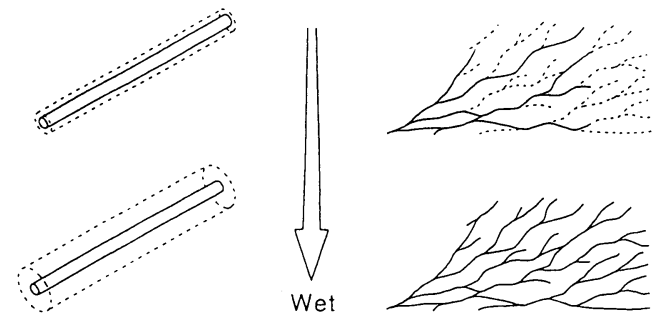

Expansion of interactive zone

Extension of macropore network
パイプとして機能する部位の拡大の概念図

(Tsuboyama et al., 1993による)

と考えられる。

さらに，同じ断面内のパイプにおいても流出の有 無がある. 降雨強度の小さいときは表一 1 に示した 下層土に発達するパイプからのみ流出が見られるが, 降雨強度が大きくなるにつれ, 表一 1 における表層 土のパイプからも流出が見られることが観察されて いる (Tsukamoto and Ohta, 1988).また, パイプが排 水システムとして働く部分は土壤の含水率及び降雨 強度の影響を受ける. Tsuboyama et al.(1994), Navar et al. (1995)は, 図一 5 に概念モデルを示す とおり, 含水率が上昇するに従いパイプとして働く 部分は大きくなることを示している.

$\mathrm{a}, \mathrm{b}$ の現象をふまえて，ここでこれまで考えら れているパイプ流発生メカニズムについて検討する。 谷(1987) は表一 1 における表層土パイプを想定し地 下水面が上昇しパイプの層に達すると流出が開始す るとした。更にその際パイプには, 古い水が押し出 し流的に供給されるとした. McDonnell(1990.a)は 表一 1 における下層土パイプを想定し, 基岩面上に 達した雨水が貯留されていた古い水と混じり, 飽和 帯を形成し, パイプ内に水が浸透しパイプ流出が生 じるとした.

これらの考えをもとに現在予想されるパイプ流発 生メカニズムについて筆者の考えを以下にまとめる。 概念図を図一 6 に示す. 降雨が地表に達し土層内を 鉛直に浸透する.難透水層(中古生層等においては基岩 面を特定することは困難である.そこで,ここでは降雨時 に飽和帯が形成しうる面以下を難透水層とする.)上に 達した雨水は貯留されていた水と混じり飽和に達す る. 図一6(a)に示すとおり, パイプのある下層土が 飽和に達することによりパイプ内に水が浸透し, パ イプ流が発生する. パイプ内に浸透した水はパイプ 


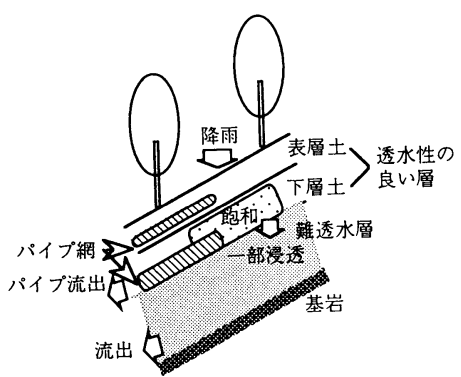

(a)

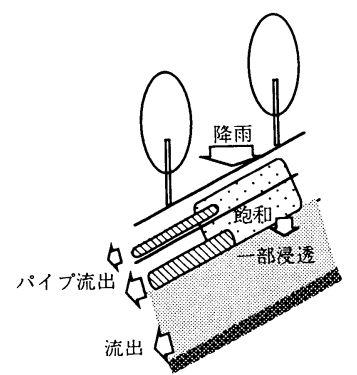

(b)

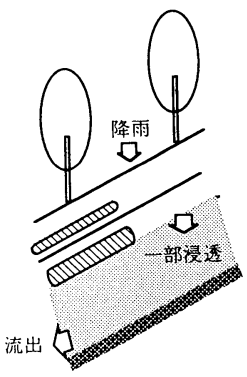

(c)

\section{図一6 パイプ流発生の概念図}

により速やかに排水されるが，図一6(b)に示すとお り，鉛直浸透流量がパイプ流量を上回ると地下水面 は上昇拡大し，より土層上部の表層土のパイプ，斜 面上部のパイプも排水システムとして働くようにな る.

パイプの存在する部位が飽和に達する条件は, 降 雨初期の土壤の含水率と降雨量の影響を受ける。す なわち, 初期の含水率が大きい場合, 降雨強度が小 さくともパイプの層は飽和に達しパイプ流が発生す る. 降雨量が大きい場合は，パイプの層はいたる所 で飽和に達し直接流出率は大きくなる. また, 図一 6 (c)に示すと抢り, 降雨強度がある一定值 (北原ら (1994 b ) の式で言う $\left.P_{a c}\right)$ に達しない限り難透水層下への鉛 直浸透または不飽和側方流として流下し，パイプの 層が飽和に達することなくパイプ流は発生しない。

しかしこれらは，パイプ内への周囲の土層からの 水の浸透量を定量的に表現できるものではない.

\section{3 . パイプ流出のモデル化}

現在までに幾つかモデルが提案されている．まず， 降水量から流出量を算出するモデルとして, キネマ ティクウェーブ法を用い流出量を再現したものがあ る. 谷(1987)は, 直接流出が主としてパイプからの流 出で賄われていると考えられる流域からの流量をキ

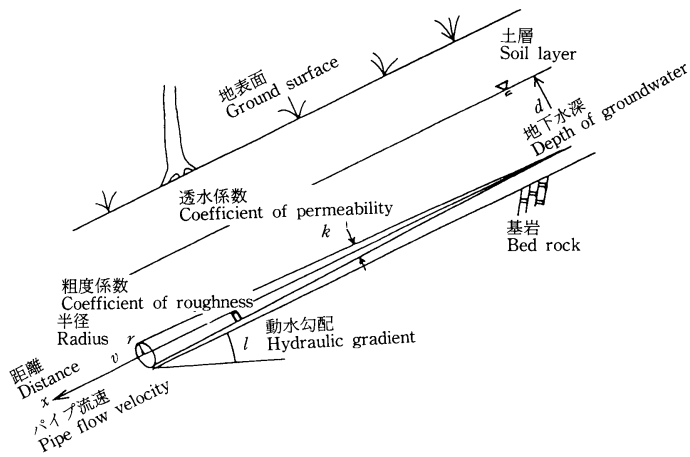

図一7 パイプモデルの概念図(北原，1995による)

ネマティクウェーブ法を用いて再現した。パラメー 夕の同定結果をもとにパイプ流がかなり速い流れで あることを示した。北原ら (1994b) は流量と流速から 算出した等価粗度を用いてパイプからの流出を再現 したところ波形は比較的良好な一致を見た。しかし， 算出結果のピーク時間, 増水開始時間は実際より早 く，これについて北原らは鉛直浸透による時間遅れ を考慮する必要があると指摘した。また，小原ら （1993）は樹幹流を水分供給源とする速い鉛直浸透と 通常のマトリックスによる遅い鉛直浸透とを考え， キネマティクウェーブ法とフィックの拡散方程式を 用いると流出水の流量及び水質変化が再現できると した.

また, 北原(1995) は地下水位からパイプの流出量 を算出するモデルを提案している，パイプからの流 出量はパイプ壁面からの浸透で賄われ，パイプ壁面 からの浸透量は透水係数と地下水位により決まると 仮定しモデル化を試みた。パイプの構造は合流分岐 のない円錐と仮定した，概念図を図一7に示す．前 述の通り, パイプ内の水の流れは, 流速が動水勾配 の $1 / 2$ 乗に比例するとし,地下水位を一定として次 の式を導いた。

$$
Q p=4.15 K^{8 / 5} n^{3 / 5} I^{-3 / 10} d^{8 / 5} x^{8 / 5}
$$

$Q p$; パイプ流量, $K$; 透水係数, $n$; マニングの 粗度係数, $I$; 動水勾配, $d$; 地下水深, $x$ : パイプの 発生点からの距離

マニングの粗度係数は実測値を用い算出した結果 と実測のパイプ流量と地下水位の関係とは比較的良 好な一致を見せるとした。

しかしこれらのモデルは必ずしも前項で検討した 課題を説明・再現するものではない.またパイプ流 の斜面安定及び崩壊への関与を検討するために, 最 終的には降水量から斜面内の地下水面形，さらに流 
出量の再現が可能な流出モデルの構築が必要となっ てくる.

最後にパイプの降雨流出過程に及ほす影響を定性 的ではあるがまとめる。

パイプには地下水を集中させる効果と通常のマト

リックスの流れ以上の速度で流下させる効果がある. これら 2 つの効果からパイプは良好な排水システム を形成しうる．またパイプの働きは土壌の水分条件 の影響を受け土㙵の含水率が高いほどその効果は大 きく, 逆に土壌の含水率が小さいときは効果は小さ く, パイプ流が発生しないこともある.

\section{III . 崩壊要因としてのパイプ}

前章で既に述べたように，パイプは，特に降雨時 において，良好な排水システムとして働くと考えら れる. しかし, 愛知県矢作川流域における68箇所の 崩壊跡地の観察から $94 \%$ の崩壊跡地でパイプが確認 され，特に崩壊跡地上縁部に多くのパイプが確認さ れた(太田ら，1981)。また, 多摩丘陵に打ける崩壊直 後の観察では, 未崩壊部分のパイプから地下水の流 出が観測された(新藤, 1983)。これらの観察結果はパ イプが良好な排水システムとして斜面安定に寄与せ ず，パイプによる水移動が斜面崩壊に関与する可能 性があることを示唆している.

そこで，通常，排水システムとして斜面安定に寄 与するパイプが崩壊に関与するメカニズムを明らか にする必要がある．本章では，図一1に示すとおり に通常の降雨時に生じると思われる現象と大きな降 雨時に生じると思われる現象とに分け，パイプによ る水移動の斜面安定に及ぼす影響について検討する。

\section{1. 通常の降雨時におけるパイプ流の斜面安定に 与える影響}

通常の降雨時におけるパイプの斜面土層に与える 影響は, 地下水帯形成にパイプが与える効果から次 の 2 点が考えられる.

(1) 良好な排水システムとしての地下水面低下効 果

(2) 不完全な排水システムによる水の集中 パイプ網は下流端が排水路に開放されており良好 な排水システムとして働くものとパイプ網下流端が 閉塞している排水システムとしては不完全なものが ある。

1) 排水システムとしての地下水面低下効果

図一 1 における $4 \rightarrow 11$ の過程に示すとおり，パイ

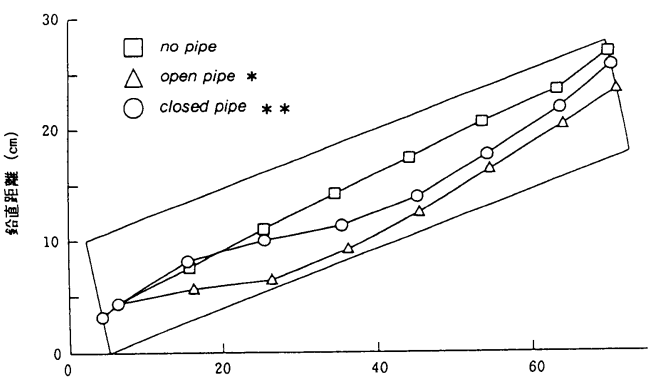

図一8 一定流量時におけるパイプ下流端の条 件の違いによる水面形の違い(内田ら， 1995 bより作成)

*下流端の開放したパイプは土層下流端 とパイプ下流端が一致

**下流層の閉塞したパイプは土層下流 端から $15 \mathrm{~cm}$ の地点の土層内にパイプ下流 端が存在.

プは斜面内の水を効果的に排水しうるため，地下水 面の上昇を抑制する効果がある．この効果は，間隙 水圧の上昇を抑制し, 側方流の地表面への復帰を防 ぎ，斜面安定に寄与すると考えられる，谷ら (1987), Sidle et al.(1995), 内田ら (1995b)は, 人工パイプ, 透水性のよいレキ層を用いた室内実験によりその効 果を検討している. 図一8に示すとおり人工パイプ 及びレキ層といった透水性の良いものを斜面内に設 置することで地下水面は低下する. また，特にパイ プ等の上流部で低下の効果が大きい.

\section{2 ) 不完全な排水システムによる水の集中}

図一 1 における $5 ， 9 \rightarrow 12$ の過程に示すとおり, 下流端の閉塞したパイプは下流端付近において水の 集中が生じる。この効果は。飽和度上昇, 間隙水圧 の増加による土質強度の低下をもたらし, 崩壊の要 因となると考えられる。

崩壊多発地域におけるピエゾ水頭は降雨に対し上 昇の応答は早く, 減衰は緩慢である。このことは, 下流端の閉塞したパイプによる地下水の早い集中及 び下流端の閉塞による緩慢な排水によると考えられ るとされている(Sidle, 1984; Brand et al., 1986).

閉塞パイプの下流端の地下水位については人工パ イプを用いた室内実験, 数值シミュレーションによ り検討されている．图一 8 に示すとおり，人工パイ プを用いた室内実験によると下流端の閉塞したパイ プの下流端部では他の位置に比べ水面の位置が高く, パイプのない時と比較しても地下水面の位置が高く なる.また，パイプの下流端部における地下水面の 上昇は給水に対して極めて応答が早いことを示した 

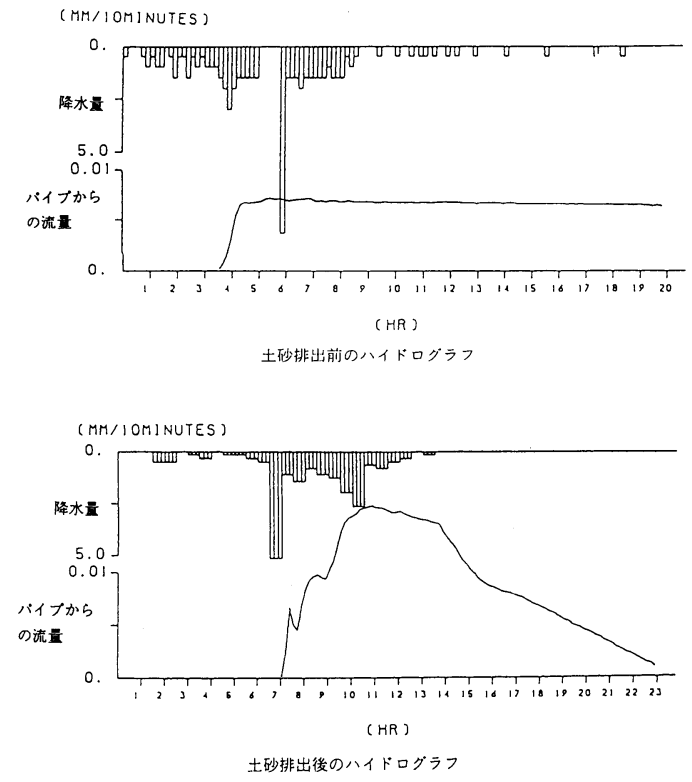

図一9 土砂排出前後におけるパイプ流出の変 化(水山ら，1994より作成)

(Pierson, 1983；内田らb, 1995).また, 透水性の大き な水みちを有したモデル斜面内の飽和不飽和の地下 水の流れを 3 次元有限要素法でシミュレーションし た結果からも, 閉塞したパイプの下流端部において は高ポテンシャルが生じることが明らかにされてい る(渡辺・今井, 1984)。

\section{2. 大きな降雨時のパイプの斜面安定に与える影 響}

大きな降雨時のパイプの斜面安定に与える影響と して図一 1 の大大きな降雨’の欄に示すとおり次の 2 点が考えられる.

(1) 大きな降雨時における排水システムの許容量 超過

(2) パイプによる地下侵食

パイプによる地下侵食は大きな降雨時にのみ起 こっているわけではない.しかし，急激な土砂生産 は豪雨時に観測される (寺嶋・佐倉, 1993)ことから, パイプの構造の急激な変化は大きな降雨時に起きる と考えられる。

1 ) 排水システムの許容量超過

パイプ流量は観測結果から，図一9に示すとおり, 上限値を持つとことがある(水山ら，1994).このこと から，パイプの流下可能量は決まっていることが考 えられる. 図一 1 に扔ける $8 \rightarrow 14$ の過程に示すとお
り，大きな降雨があり，流下可能量を超える水がパ イプの地下水集中効果によりパイプ内に集中したと き，パイプは集中した水を速やかに流下することが できなくなり，パイプ内に急激な水圧の上昇が生じ, 斜面を不安定にする要因となると考えられる. その とき水圧の上昇の生じる場所として，パイプの断面 積が一番小さい所(McDonnell, 1990b)，パイプ内の 粗度の一番大きい所(北原，1995)などが考えられる.

このことは，パイプは前項で述べた下流端の閉塞 したパイプでなくとも，大きな降雨時においては斜 面を不安定にする側に働くことがあり得ることを示 唆している.

\section{2 ) パイプによる地下侵食}

図一 1 に示す通り地下侵食が斜面に与える影響と して以下の 3 点が挙げられる.

a . 排水システムの形成・発達

パイプからの土砂の排出は, パイプからの流出量 に影響を与える．図一9 に示す通り土砂排出後は同 程度の雨量であっても流出量が変化する. 土砂排出 後はパイプ流出のハイドログラフのピーク流量は大 きくなり, ピークの波形は鋭くなる(水山ら, 1994).こ のことから，図一 1 における $2 \rightarrow 1 \rightarrow 4 \rightarrow 11$ の過程 に示すとおり，地下侵食により良好な排水システム が構築され，斜面安定に地下侵食が奇与したと考え られる。

$\mathrm{b}$ ．排水システムの破壊

一方，パイプ内の落盤・目詰まりが生じ，パイプ が急激な閉塞を起こす可能性もある。図一 1 におけ る $7 \rightarrow 10 \rightarrow 14$ の過程に示すとおり，地下侵食による パイプの閉塞は，排水システムを破壊しパイプ内に 水圧の急激な上昇を引き起こす。パイプ内の急激な 水圧の上昇により，周囲の土層の間隙水圧の上昇も 引き起こされることが予想されている(太田ら, 1981 ; 新藤, 1993)。これによる急激な間隙水圧の増 加・飽和度上昇は，土質強度の低下をもたらす。

しかしながら, 斜面方向のパイプの閉塞メカニズ ム, 閉塞条件については実証的に明らかにされてい るとはいえない.

c . 斜面内に「緩み」の発生(図一 1 における $6 \rightarrow 13$ の過程)

大きな降雨時にパイプからの土砂生産が観測され た斜面の上部には陥没，崩壊が見られることがある. このような現象は急傾斜な谷の側壁斜面及び谷頭部 において見られる。このことから，パイプ流による 地下侵食は舟底型谷地形の形成及び 0 次谷の成長に 
寄与すると考えられる (恩田・新藤, 1987 ; 寺嶋・佐 倉, 1993).

新藤 (1993) はこれらの現象も含めて「繰り返し発 生する集中流によって進行する地下侵食に起因する 現象で，斜面の緩みをきたしたり，空洞が陥没する ことによる斜面の不安定化」を「斜面の疲労現象」 とした。

\section{IV. おわりに}

パイプ流が斜面土層に与える影響についての研究 についてレビューした．最後に今後の課題について 整理する，パイプが斜面安定に与える影響の中で一 番大きいものは降雨時における地下水面形成に与え る影響であると考えられる。パイプが地下水面形成 に与える影響を検討するにあたっての課題は

1. 普遍的な現象なのか検証する

2 . 定量的に評価する

3 . 動的変化を評価する

の 3 点が考えられる。

既に述べてきたこれまで行われてきた研究成果が， 他の流域，他のパイプに適応可能か否かを検討する 必要がある，その上で，可能であればパイプを一定 の基準(例えば表一 1 に示した分類)により分類し，こ れまでの研究結果をどの範囲のパイプにおいて適用 できる結果であるかを検証する必要がある。

パイプの地下水面形成に与える影響を定量的に評 価するためにパイプを含めた流出モデルの構築が必 要である，最終的に望まれる流出モデルは単に流出 量を再現するのみでなく，地下水面形をも再現でき る必要がある.そのための課題として，(1)パイプの 構造の定量化，(2)パイプ内の運動則の解明，(3)パイ プ流発生機構の解明をあげた. パイプ内の運動則は 北原(1989)においてかなり解明されてきている。し かしながら(1)については，それぞれのパイプにより 構造が違うため，多くのパイプを観察する必要があ り，解明には時間がかかると思われる。一方，パイ プ流の発生機構についてはほとんど実証的に解明さ れておらず，想像の域をでていない．まず解明すべ き問題と考える。

崩壊，斜面安定を考えるためには，地下水面形の 時間変化を考える必要がある，既に指摘したとおり， 降雨時においてパイプ内に水が集中し，かなりの流 速，流量で流下しているとき，パイプ内では土砂の 生産・輸送が生じていることがある。このことはパ イプの構造が変化することを示しており，地下水面
形成に影響を与える可能性が高い.そこで，パイプ 内の土砂生産・輸送のメカニズムを明らかにし，パ イプの構造の時間変化と流出形態の時間変化を検討 する必要がある。

謝辞：本稿をまとめるにあたって京都大学農学部小 橋澄治教授の指導を受けた。記して謝意を表します。

\section{参考文献}

Beven, K., P. Germann (1982): Macropores and Water Flow in Soils, Water Resour. Res. 18, pp. 1311-1325

Brand, E.W., M.J. Dale, J.M. Nash (1986): Soil pipes and slope stability in Hong Kong, Q. J. Eng. Geol., 19, pp. 301-303

Jones, J .A.A (1971): Soil piping and stream channel initiation, Water Resour. Res., 7, pp. 602-610

北原 曜(1988)：林地緩斜面土層中のパイプフロー の特性，日林誌，70, pp. 318-323

北原 曜(1989)：林地緩斜面土層中のパイプフロー の特性(II)パイプの水理特性, 日林誌, 71, pp. 317-322

北原 曜, 中井裕一郎(1992)：一次谷流域における 河川流量とパイプ流の関係, 日林誌, 74, pp. 49-54 北原 曜, 寺嶋智巳, 中井裕一郎 (1994a)：側方浸透 流量に占めるパイプ流量の割合, 日林誌, $76, \mathrm{pp}$. 10-17

北原 曜, 三森利昭, 寺嶋智巳, 中井裕一郎 (1994 b ) : 降雨に対するパイプ流とマトリックス流の 応答，水・水学会1994年要旨集, pp. 12-13

北原 曜(1995)：森林土層中の水移動におけるパイ プ孔隙の特性に関する研究，森林総研研報， 367 , pp. 63-115

小山 敢, 奥村武信, 中島 剛, 衣川和幸, 黒木道 代,（1994）：火山性堆積物小流域でのパイプ流に 関する観測研究，水文・水資源学会1994年要旨集, pp. $306-309$

McDonnell, J.J. (1990a): A rational for old water discharge through macropores in a steep, humid catchment, Water Resour. Res., 26, pp. 2821-2832

McDonnell, J.J. (1990b): The influence of macropores on debris flow initiation, Q.J. Eng. Geol., 23, pp. 325-331 
水山高久, 佐藤一朗, 小杉賢一朗 (1994)：芦生演習林 内ト七ノ谷におけるパイプ流出とパイプ網に関す る研究, 京大演報, 66, pp. 48-60

Mosely, M.P. (1982): Subsurface flow velocities through selected forest soil, South Island, New Zealand, J. Hydrol., 55, pp. 65-92

Nieber, J.L., G.S. Warner (1991): Soil pipe contribution to steady subsurface stormflow, Hydro. Process., 5, pp. 329-344

Navar, J., D.J. Turton, E.L. Miller (1995): Estimating macropore and matrix flow using the hydrograph separation procedure in an experimental forest plot, Hydro. Process., 9, pp. $743-753$

小原裕博, 松林宇一郎, 高木不折 (1993)：山腹斜面に おける雨水流出経路に関する研究, 土木学会年次 講演会要旨集, pp. 212-213

太田猛彦, 塚本良則, 野口晴彦(1981）：パイプフロー と山崩れについての一考察, 昭和56年砂防学会発 表会概要集，pp. 92-93

恩田裕一, 新藤静夫(1988)：いわゆる舟底型地形の 形成におけるパイプ流侵食の意味, 地形, 9, p. 58

Pearce, A.J., M.K. Stewart, M.G. Sklash (1986): Storm runoff generation in humid headwater catchments, 1, Water Resour. Res., 22, pp. 1263-1272

Pierson, T.C. (1983): Soil pipes and slope stability, Q.J. Eng. Geol., 16, pp. 1-11

新藤静夫 (1983) : 谷頭部斜面に発生する崩壊と地中 水の挙動, 文部省科学研究費自然災害特別研究

新藤静夫, 丹下 勲, 寺島治男 (1988)：斜面末端部に 抢ける地中水の挙動, 波丘地研究, 6, pp. 124-145 新藤静夫 (1993)：斜面災害における地中水の集中流 現象，第四紀研究，32，pp. 315-322

Sklash, M.G., M.K. Stewart, A.J. Pearce (1986): Storm runoff generation in humid headwater catchments, 2, Water Resour. Res., 22, pp. 1273-1282

Sidle, R.C. (1984): Shallow groundwater fluctuation in unstable hillslope of Alaska, Z. Glets- cherkunde und Glazialgeol., 20, pp. 79-95 Sidle, R.C., H. Kitahara, T. Terajima, Y. Nakai (1995): Experimental studies on the effects of pipeflow on throughflow partitioning, J. Hydro., 165, 207-219

田中 正, 安原正也, 丸井敦尚（1984）：多摩丘陵源 流域における流出機構，地理評，57, pp. 1-19

谷 誠(1987)：森林土壤の水源函養効果の解明に向 けて，水利科学， 177, pp. 35-61

谷 誠, 阿部敏夫, 小林忠一, 服部重昭(1987)：斜面 土層内の暗渠が雨水流出に及ほす影響, 日林論,

98, pp. 751-752

寺嶋智巳，佐倉保夫(1993)：花崗岩山地谷頭部の地 形変化に及ぼす斜面浸透流の作用, 地形, 14, pp. 365-384

Tsuboyama, Y., R.C. Sidle, S. Noguchi, I. Hosoda (1994): Flow and solute transport through the soil matrix and macropores of a hillslope segment, Water Resour. Res., 30, pp. $879-890$

塚本良則, 峰松浩彦, 丹下 勲(1988)：斜面表層に発 達する地中パイプ，波丘地研究，6，pp. 286-180 Tsukamoto, Y., T. ohta (1988): Runoff processes on a steep forested slope, J. Hydro., 102, pp. $165-178$

塚本良則 (1992)：森林水文学,p. 136，文永堂出版 内田太郎，小杉賢一朗，小橋澄治，水山高久(1995 a ) : 芦生演習林内卜七ノ谷のパイプ網の観測, 京 大演報, 67, pp. 58-67

内田太郎，小杉賢一朗，大手信人，水山高久 (1995 b ）：斜面土層内のパイプが地下水面形に及ぼす 影響に関する実験的研究，日林論，106, pp. 505-508

安原正也, 田中 正, 丸井敦尚 (1984)：多摩丘陵の二 つの現流域におけるパイプの形成とその水文学的 環境，地形，5，pp. 125-137

渡辺邦夫・今井 久(1984)：水みちを持つ斜面内の 非定常地下水流れの性質，応用地質，25，pp. 1-8 （1996年 2 月13日受付，1996年 4 月18日受理） 